\title{
Adrenal Cortical Carcinoma pN1 TNM
}

Finding v8

National Cancer Institute

\section{Source}

National Cancer Institute. Adrenal Cortical Carcinoma pN1 TNM Finding v8. NCI

Thesaurus. Code C141097.

Metastasis in regional lymph node(s). (from AJCC 8th Ed.) 